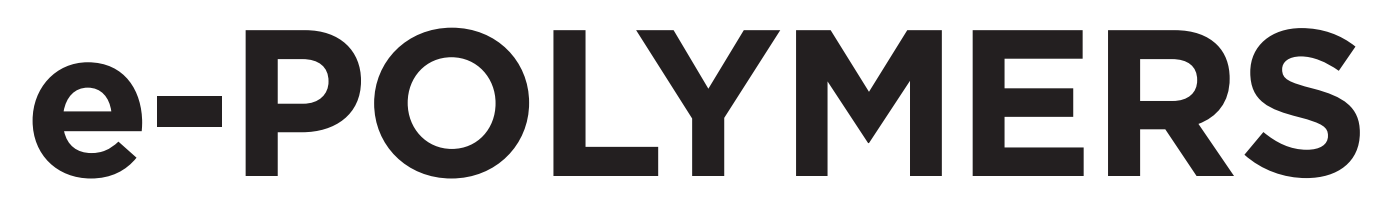

EDITORS-IN-CHIEF

Seema Agarwal, Bayreuth, Germany

Andreas Greiner, Bayreuth, Germany

\title{
EDITOR
}

Jian Ji, Hangzhou, China

\section{FOUNDING EDITORS}

Hartwig Hoecker

Stanislaw Penczek

EDITORIAL ADVISORY BOARD

Felix Schacher, Jena, Germany

Susanta Banerjee, Kharagpur, India

Prasad Shastri, Freiburg, Germany

Stephen Eichhorn, Exeter, UK

Zhu Meifang, Shanghai, China

Yasuhiko Iwasaki, Osaka, Japan

Piming Ma, Jiangsu, China

Stan Slomkowski, Lodz, Poland

Tamer Uyar, Ankara, Turkey 
ABSTRACTED/INDEXED IN Celdes, Chemical Abstracts Service (CAS), Chemical Abstracts Service (CAS) - SciFinder, CNPIEC, EBSCO Discovery Service, Electronic Journals Library, Elsevier - SCOPUS, J-Gate, Naviga (Softweco), Polymer Library, Primo Central (ExLibris), SCImago (SJR), Summon (Serials Solutions/ProQuest), TDOne (TDNet), TEMA Technik und Management, Thomson Reuters - Current Contents/Physical, Chemical and Earth Sciences, Thomson Reuters - Science Citation Index, Thomson Reuters - Science Citation Index Expanded, Ulrich's Periodicals Directory/ ulrichsweb, WorldCat (OCLC)

The publisher, together with the authors and editors, has taken great pains to ensure that all information presented in this work (programs, applications, amounts, dosages, etc.) reflects the standard of knowledge at the time of publication. Despite careful manuscript preparation and proof correction, errors can nevertheless occur. Authors, editors and publisher disclaim all responsibility for any errors or omissions of liability for the results obtained from use of the information, or parts thereof, contained in this work.

The citation of registered names, trade names, trademarks, etc. in this work does not imply, even in the absence of a specific statement, that such names are exempt from laws and regulations protecting trademarks etc. and therefore free for general use.

ISSN $2197-4586 \cdot$ e-ISSN $1618-7229$

All information regarding notes for contributors, subscriptions, Open access, back volumes and orders is available online at www.degruyter.com/journals/epoly

RESPONSIBLE EDITORS Prof. Dr. Seema Agarwal, Chair of Macromolecular Science II, University of Bayreuth, Building NW II, Universitätsstraße 30, 95440 Bayreuth, Tel.: +49-921-553397, Email agarwal@uni-bayreuth.de

Prof. Dr. Andreas Greiner, Chair of Macromolecular Science II, University of Bayreuth, Building NW II, Universitätsstraße 30, 95440 Bayreuth, Tel.: +49-921-553399, Email greiner@uni-bayreuth.de

JOURNAL MANAGER Holger Kleeßen, De Gruyter, Genthiner Straße 13, 10785 Berlin, Germany, Tel.: +49 (0)30 260 05-348, Fax: +49 (0)30 260 05-184, Email: epolymers.editorial@ degruyter.com

RESPONSIBLE FOR ADVERTISEMENTS Claudia Neumann, De Gruyter, Genthiner Straße 13, 10785 Berlin, Germany, Tel.: +49 (0)30 260 05-226, Fax: +49 (0)30260 05-264, Email: anzeigen@ degruyter.com

(C) 2016 Walter de Gruyter GmbH, Berlin/Boston

TYPESETTING Compuscript Ltd., Shannon, Ireland

PRINTING Franz X. Stückle Druck und Verlag e.K., Ettenheim

Printed in Germany

COVER ILLUSTRATION Two metal acetate-ethanolamine complexes, namely $\mathrm{Cu}(\mathrm{OAc})_{2}(\mathrm{EA})$ and $\mathrm{Zn}(\mathrm{OAc})_{2}(\mathrm{EA})$, were synthesized from metal acetates $\left[\mathrm{M}(\mathrm{OAc})_{2}\right.$, where $\mathrm{M}=\mathrm{Cu}$ and $\left.\mathrm{Zn}\right]$ and ethanolamine (EA). These metal acetate-ethanolamine complexes can be used as catalysts in the preparation of rigid polyurethane (RPUR) foams. Both $\mathrm{Cu}(\mathrm{OAc})_{2}(\mathrm{EA})$ and $\mathrm{Zn}(\mathrm{OAc})_{2}(\mathrm{EA})$ were obtained as viscous liquids, which have very weak odor and could be easily dissolved in the starting materials of RPUR foam formulation. The results were compared with RPUR foam prepared from dimethylcyclohexylamine (DMCHA), which is a commercial catalyst with very strong amine odor. Considering the gel time and rise time, $\mathrm{Cu}(\mathrm{OAc})_{2}(\mathrm{EA})$ had higher catalytic activity than $\mathrm{Zn}(\mathrm{OAc})_{2}(\mathrm{EA})$ and both metal acetate-ethanolamine complexes had lower catalytic activity than DMCHA. Density and compressive strength of RPUR foam catalyzed by $\mathrm{Cu}(\mathrm{OAc})_{2}(\mathrm{EA})$ were comparable to that prepared from DMCHA.

For more information on this topic please read the article on Preparation of rigid polyurethane foams using low-emission catalysts derived from metal acetates and ethanolamine by Duangruthai Sridaeng, Wannisa Jitaree, Preecha Thiampanya and Nuanphun Chantarasiri on pages 265-275 in this issue. (DOI: 10.1515/epoly-2016-0021).

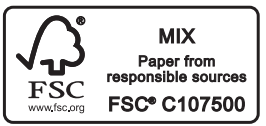




\section{Contents}

\section{Full length articles}

Duangruthai Sridaeng, Wannisa Jitaree, Preecha Thiampanya and Nuanphun Chantarasiri

Preparation of rigid polyurethane foams using lowemission catalysts derived from metal acetates and ethanolamine - 265

Stefan Oprea and Veronica Oprea

Biodegradation of crosslinked polyurethane acrylates/ guar gum composites under natural soil burial conditions -277

Szymon Żaczek, Agnieszka Pająk, Rafał Anyszka and Grażyna Janowska

Influence of phthalocyanine pigments on the properties of flame-retardant elastomeric composites based on styrene-butadiene or acrylonitrile-butadiene rubbers -287

Yonglin Lei, Yuanjie Shu, Jinhua Peng, Yongjian Tang and Jichuan Huo

Synthesis and properties of low coefficient of thermal expansion copolyimides derived from biphenyltetracarboxylic dianhydride with p-phenylenediamine and 4,4'-oxydialinine - 295

Yan-Hua Cai and Li-Sha Zhao

Thermal behavior of modified poly(L-lactic acid): effect of aromatic multiamide derivative based on 1H-benzotriazole - 303
Dun Chen, Tunsagnl Awut, Bin Liu, Yali Ma, Tao Wang and Ismayil Nurulla

Functionalized magnetic $\mathrm{Fe}_{3} \mathrm{O}_{4}$ nanoparticles for removal of heavy metal ions from aqueous solutions - 313

J. Sahari and M.A. Maleque

Effect of oil palm ash on the mechanical and thermal properties of unsaturated polyester composites - 323

Rushali Singh, Ashwani Mathur, Navendu Goswami and Garima Mathur

Effect of carbon sources on physicochemical properties of bacterial cellulose produced from Gluconacetobacter xylinus MTCC $7795-331$

Xin Sanfa and Wang Xinhou Investigation into the effect of the angle of dual slots on an air flow field in melt blowing via numerical simulation 337

Ya-Juan Su, Ze-Xin Ma and Jian-Hua Huang Simulation study on the assembly of rod-coil diblock copolymers within coil-selective nanoslits _ 343 